DOI: https://doi.org/10.24867/02AM07Gutovic

\title{
ПРИМЈЕНА ТОПЛОТНИХ ПУМПИ КОД ОБЈЕКАТА РАЗЛИЧИТЕ ЕНЕРГЕТСКЕ ЕФИКАСНОСТИ
}

\section{APPLICATION OF HEAT PUMPS IN BUILDINGS WITH DIFFERENT ENERGY EFFICIENCY}

Драгиша Гутовић, Факултет техничких наука, Нови Сад

\section{Област - МАШИНСТВО}

Кратак садржај - Задатак овога рада јесте да представи топлотне пумпе као енергетски и еколошки добро решење у системима гријања који се користе у стамбене сврхе. Описан је основни принцип на коме се заснива рад топлотне пумпе, топлотни извори које она користи и дата је основна подјела топлотних пумпи које се највише користе у овакве сврхе. Приказана је симулачија топлотне пумпе ваздух/вода која се користи за гријање и припрему топлоте потрошне воде у домаћинству за три основна случаја: високо, просјечно и ниско енергетски ефикасан објекат. Спроведена је анализа како енергетска ефикасност објекта утиче на енергетске, еколошке и економске параметре.

Кључне ријечи: Топлотна пумпа, GeoT*SOL, енергетска ефикасност.

Abstract - The aim of this paper is to present heat pumps as energy and environmentally sound solution in heating systems that are used for residential purposes. The basic principle the operation of the heat pump relies on is presented as well as thermal sources and the most commonly types of heat pumps used for such purposes. The simulation of an air-water heat pump used for water preparation and heating is given for three basic cases: high, average and low energy efficient facility. The analyses how energy efficiency takes a part in energy, ecological and economic parameters is showed as well.

Keywords: Heat pump, GeoT*SOL, energy efficiency.

\section{1. УВОД}

Највећи дио топлотне енергије потребан за гријање стамбених и других објеката гдје бораве људи обезбеђује се употребом фосилних горива.

Коришћење енергије из обновљивих извора енергије постаје све популарније како расте свест о планирању будућности сваке земље када залихе фосилних горива буду при крају.

\section{НАПОМЕНА:}

Овај рад проистекао је из мастер рада чији ментор је био доц. др Александар Анђелковић.

\section{2. ПРИНЦИП РАДА И РАЗВОЈ ТОПЛОТНЕ ПУМПЕ}

Топлотне пумпе у данашње вријеме се убрајају у најефективније уређаје помоћу којих се добија топлотна енергија. за гријање у стамбеним зградама која би замијенила фосилна горива.
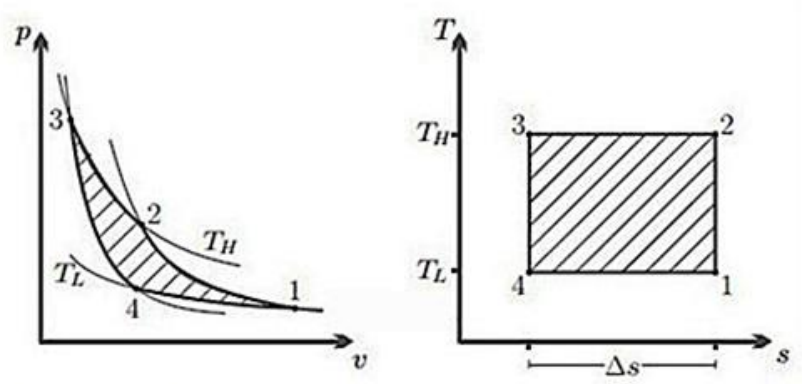

Слика 1: Карноов лијевокретни кружни цииклус

Топлотна пумпа ради на принципу Карноов-ог кружног циклуса који чине двије изотермне и двије изентропне промјене стања. Овај циклус је реверзибилан што значи да сваки процес може да промијени смјер одигравања.

\section{3. КОМПОНЕНТЕ ТОПЛОТНИХ ПУМПИ}

Топлотне пумпе се састоје од четири главне компоненте: испаривача, компресора, кондензатора и експанзионог елемента.

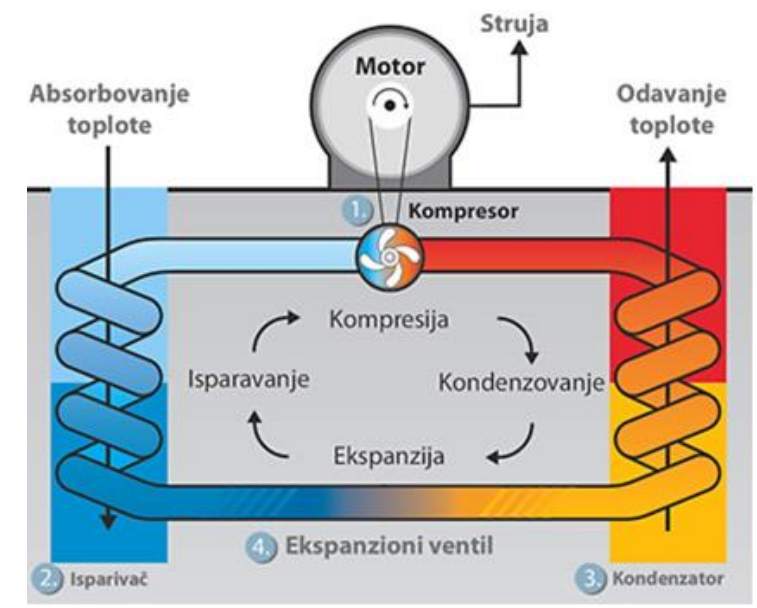

Слика 2: Шема рада топлотне пумпе

Може се слободно рећи да су један од најважнијих елемената топлотних пумпи компресори. Задатак 
компресора је да усисава пару расхладног флуида из испаривача и да је дигне на виши енергетски ниво тј. виши притисак и температуру. Конднезатори су размјењивачи топлоте који представљају важан дио система топлотних пумпи. У њему се пара расхладног флуида кондензује предајућу топлоту кондензације флуиду којим се хлади тј. топлотном понору.

Испаривачи су размјењивачи топлоте који користе топлоту окружења тј. топлотног извора за испаравање течног расхладног флуида који циркулише кроз њега. Улога експанзионог вентила је да одржава константан притисак у испаривачу. Избор најпогоднијег расхладног флуида утиче прије свега на животну средину, сигурност, поузданост и трошкове које такав систем проузрокује.

\section{4. ТОПЛОТНИ ИЗВОРИ И ПОНОРИ}

Топлотни извор представља мјесто из кога се „црпи“ топлотна енергија а топлотни понор мјесто на кога са топлотна енергија преноси. Који ће се топлотни извор употријебити зависи од расположивости, приступачности и енергетског нивоа извора. Топлотни извор треба да има високу и константну температуру током године и да има довољну издашност како би његово експлоатисање било на задовољавајућем нивоу. Ваздух је један од најприступачнијих топлотних извора и што је најважније има га у неограниченим количинама и бесплатан је (не захтијева никаква посебна одобрења).

\section{5. ВРСТЕ ТОПЛОТНИХ ПУМПИ}

На основу извора додатне енергије топлотне пумпе се дијеле на компресионе и абсорпционе. Основни извори за топлотну енергију пумпе су: ваздух, вода и земља. Када топлотна пумпа покрива $100 \%$ топлотног оптерећења каже се да ради у моновалентном режиму. За други случај када топлотна пумпа ради у спрези са неким другим извором енергије каже се да ради у бивалентном режиму. Такође је могуће остварити и друге начине повезивања топлотне пумпе и других обновљивих и необновљивих извора енергије које носе заједнички назив хибридни системи.

\section{GEOT*SOL COФTBEP}

GeoT*SOL je професионални алат за планирање и пројектовање система топлотне пумпе. Помоћу њега можемо одабрати различите врсте и компоненте система, израчунати енергију и трошкове како бисмо остварили најбољи могући сезонски фактор учинка. GeoT*SOL такође симулира системе топлотне пумпе у складу са потребама у комбинацији са соларним термичким колекторима.

\section{7. СИМУЛАЦИЈА ТОПЛОТНЕ ПУМПЕ ВАЗДУХ/ВОДА}

У овом раду биће анализирана случај инсталације топлотне пумпе ваздух/вода помоћу којих се преноси топлота на систем нискотемпературног (подног) гријања. Такође је у симулацију узета у обзир и потрошња топле санитарне воде. Симулација је одрађена на примјеру породичног стамбеног објекта нето површине $100 \mathrm{~m}^{2}$. Анализа система ће бити одрађена на три базна случају тј. на примјерима:

- Високо енергетски ефикасног објекта $\left(30 \mathrm{~W} / \mathrm{m}^{2}\right)$

- Просјечно енергетски ефикасног објекта $\left(45 \mathrm{~W} / \mathrm{m}^{2}\right)$

- Ниско енергетски ефикасног објекта $\left(90 \mathrm{~W} / \mathrm{m}^{2}\right)$

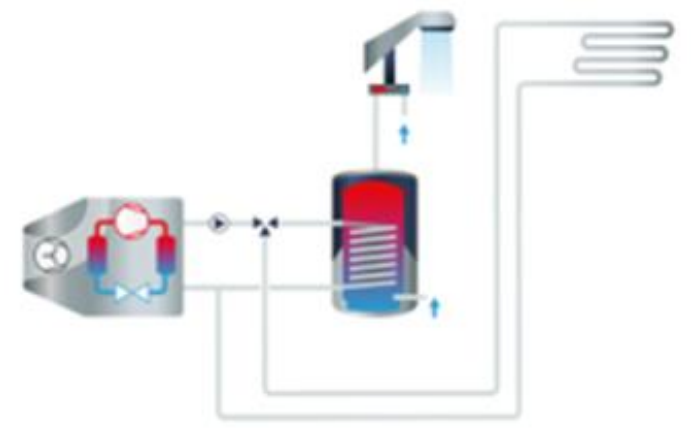

Слика 3: Систем ТП за гријање простора и ТПВ (ваздух/вода)

\section{1. Топлорна пумпа ваздух/ваздух за високо ЕE објекат}

У овом случају ће бити анализиран случај када објекат има специфичну потрошњу топлоте $30 \mathrm{~W} / \mathrm{m}^{2}$ (класа $\mathrm{K}_{1}$ разред $\mathrm{R}_{4}$ ).

Табела 1: Резултати годишње симулащије ТП ваздух/вода за високо ЕЕ објекат

\begin{tabular}{|l|l|c|}
\hline Енергија потребна за гријање објекта: & 2.918 & $\mathrm{kWh}$ \\
\hline Енергија потребна за ТПВ: & 2.834 & $\mathrm{kWh}$ \\
\hline Енергија испоручена помоћу ТП: & 6.058 & $\mathrm{kWh}$ \\
\hline Енергија испоручена електричним гријачем: & 64 & $\mathrm{kWh}$ \\
\hline Сезонски фрактор перформансе ТП: & 3,5 & - \\
\hline Сезонски фактор перформансе система ТП: & 3,4 & - \\
\hline Потрошња електричне енергије ТП: & 1736 & $\mathrm{kWh}$ \\
\hline Потрошња електричне енергије гријача: & 64 & $\mathrm{kWh}$ \\
\hline Потрошња ел. енергије пумпе топлотног извора: & 0 & $\mathrm{kWh}$ \\
\hline Губици резервоара (бојлера): & 369 & $\mathrm{kWh}$ \\
\hline Примарна уштеда енергије: & 4.839 & $\mathrm{kWh}$ \\
\hline Смањење СО 2 емисије: & 1.198 & $\mathrm{~kg}$ \\
\hline
\end{tabular}

kWh Performance factor

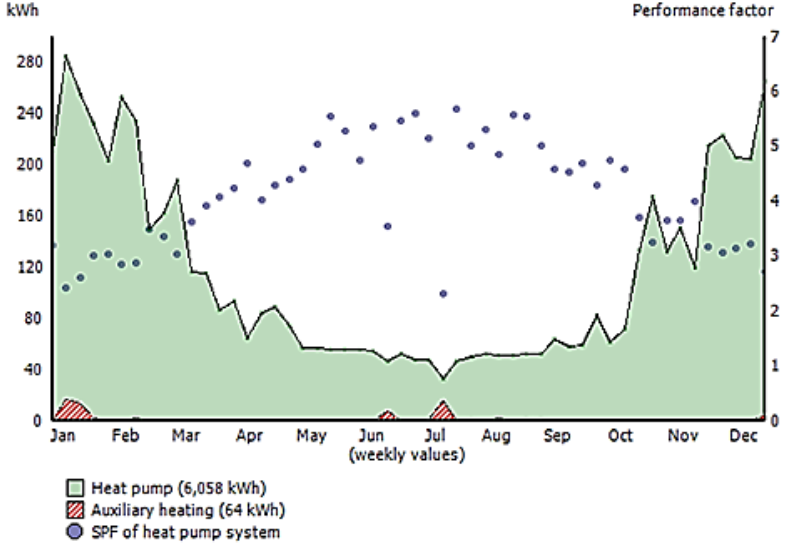

Слика 4: Енергетски дијаграм и промјена $S P F$ фактора током године - ТП ваздух/вода високо ЕE објекат 


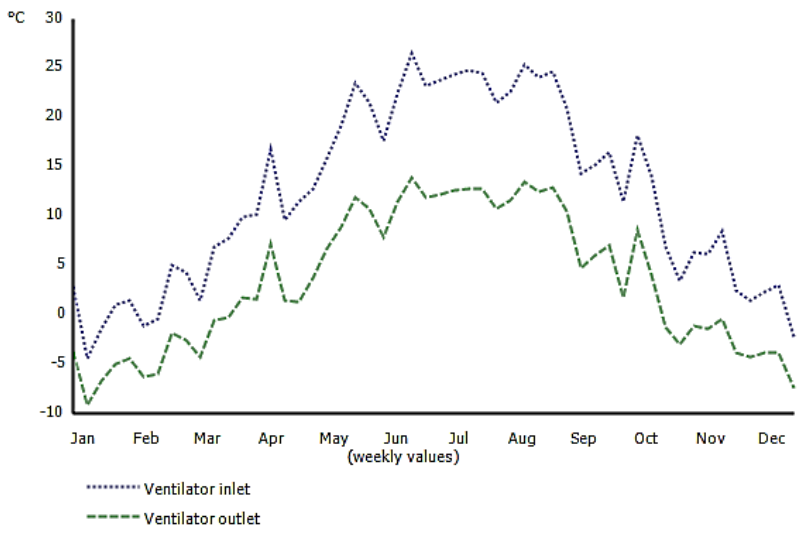

Слика 5: Температурски дијаграм - ТП ваздух/вода високо ЕЕ објекат

За покривање вршних оптерећења користи се уграђен електрични гријач који помаже да се пројектовано топлотно оптерећење оствари (Слика 4.). Ради стицања реалније слике о систему топлотне пумпе ваздух/вода, овај систем је упоређен са системом гријања на гас (гасни котао-подно гријање).

Из табеле 14. може се видјети да је цијена kWh топлотне енергије која је испоручена системом топлотне пумпе ваздух/вода за 27,70 \% мања од система гријања на гасни котао. Иако је цијена почетне инвестиције топлотне пумпе ваздух/вода за око 3,75 пута већа од инвестиције за котао на гас ипак постоје годишње новчане уштеде јер се за сваку гријну сезону мора утрошити одређена количина гаса чија је цијена подложна мањим или већом осцилацијама.

Ако би се у оваквом систему користила циркулација топле потрошне воде у циљу постизања већег комфора захтјеви за топлотом енергијом би се повећали за 984 kWh.

\section{2. Топлорна пумпа ваздух/ваздух за просјечно ЕE објекат}

За случај просјечно енергетски ефикасног објекта 45 $\mathrm{W} / \mathrm{m}^{2}$ (класа $\mathrm{K}_{2}$ разред $\mathrm{R}_{6}$ ) резултати симулације за топлотну пумпу ваздух/вода су приказани у следећој табели:

Табела 2: Резултати годишье симулације ТП земља ваздух/вода просјечно ЕЕ објекат

\begin{tabular}{|l|l|l|}
\hline Енергетска потреба гријања простора: & 5.189 & $\mathrm{kWh}$ \\
\hline Енергија потребна за ТПВ: & 2.834 & $\mathrm{kWh}$ \\
\hline Енергија испоручена помоћу ТП: & 8.256 & $\mathrm{kWh}$ \\
\hline Енергија испоручена електричним гријачем: & 134 & $\mathrm{kWh}$ \\
\hline Сезонски фактор перформансе ТП: & 3,7 & - \\
\hline Сезонски фактор перформансе система ТП: & 3,5 & - \\
\hline Потрошња електричне енергије ТП: & 2.240 & $\mathrm{kWh}$ \\
\hline Потрошња електричне енергије гријача: & 134 & $\mathrm{kWh}$ \\
\hline Потрошња ел. енергије пумпе топлотног извора: & 0 & $\mathrm{kWh}$ \\
\hline Губици резервоара (бојлера): & 368 & $\mathrm{kWh}$ \\
\hline Примарна уштеда енергије: & 6.800 & $\mathrm{kWh}$ \\
\hline Смањење СО е емисије: & 1.683 & $\mathrm{~kg}$ \\
\hline
\end{tabular}

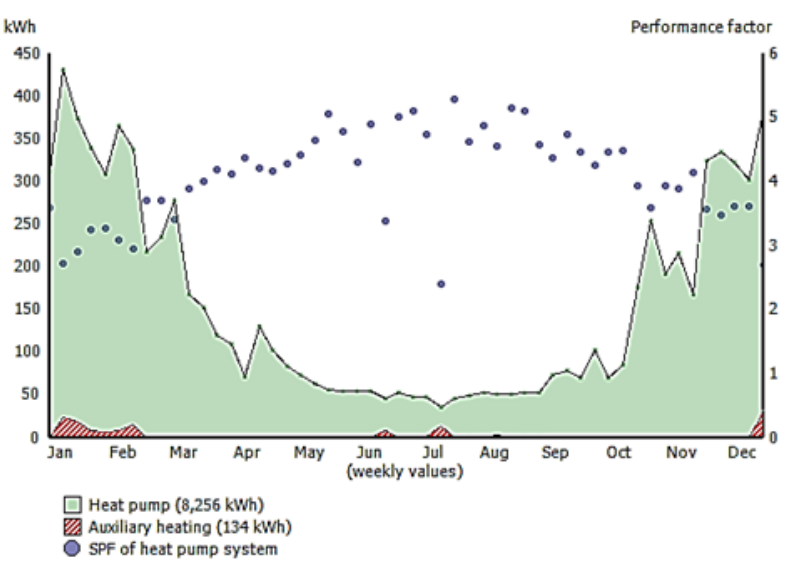

Слика 6: Енергетски дијаграм и промјена SPF фактора током године - ТП ваздух/вода просјечно EE објекат

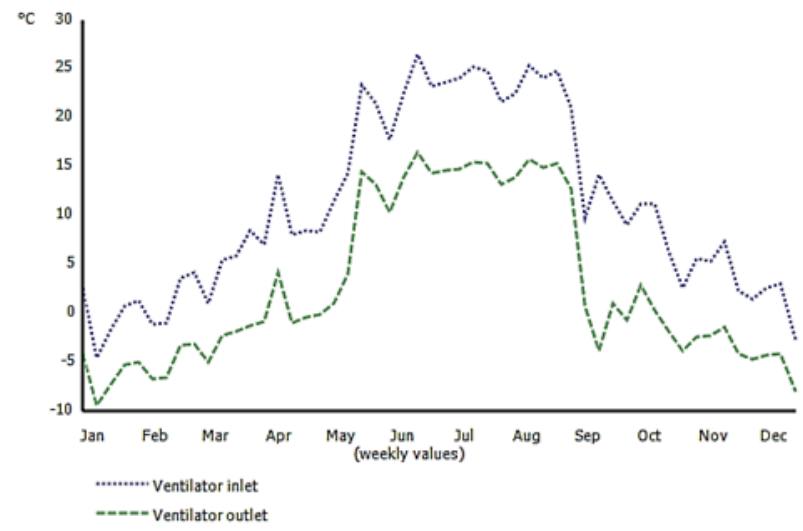

Слика 7: Температурски дијаграм - ТП ваздух/вода просјечно ЕЕ објекат

Због осцилација ваздуха температура ваздуха, температуре на улазу и на излазу из вентилатора осцилују што се може видјети из приложеног дијаграма (Слика 7.). Снижавањем температуре околног ваздуха коефицијент гријања опада што неповољно утиче на економску рачуницу. Оно што карактерише овај случај јесте већа специфична потрошња топлоте по $\mathrm{m}^{2}$ тј. 45 $\mathrm{W} / \mathrm{m}^{2}$ самим тим већи су и захтјеви за топлотном енергијом (класа $\mathrm{K}_{2}$ разред $\mathrm{R}_{6}$ ).

Топлотна пумпа ваздух/вода је у бивалентној паралелној спрези са електричним гријачем од $1 \mathrm{~kW}$ који се активира када су пикови за топлотном енергијом велики. Енергија коју испоручи овакав систем у овом случају је за $37,04 \%$ већа од енергије коју испоручи систем у претходном случају. Ако би се користио систем са циркулацијом топле потрошне воде губици би се повећали за додатних $893 \mathrm{~kW}$ у односу на систем без циркулације. У поређењу са гасним котлом истих карактеристика цијена $\mathrm{kWh}$ топлотне енергије за 69,36 \% нижа од цијене гријања на гас.

\section{3. Топлорна пумпа ваздух/ваздух за ниско ЕE објекат}

За случај ниско енергетски ефикасног објекта 90 $\mathrm{W} / \mathrm{m}^{2}$ (класа $\mathrm{K}_{3}$ разред $\mathrm{R}_{8}$ ) резултати симулације за 
топлотну пумпу ваздух/вода су приказани у следећој табели:

Табела 3: Резултати годишње симулаичје ТП земља ваздух/вода ниско ЕЕ објекат

\begin{tabular}{|l|l|l|}
\hline Енергетска потреба гријања простора: & 12.539 & $\mathrm{kWh}$ \\
\hline Енергија потребна за ТПВ: & 2.834 & $\mathrm{kWh}$ \\
\hline Енергија испоручена помоћу ТП: & 15.518 & $\mathrm{kWh}$ \\
\hline Енергија испоручена електричним гријачем: & 232 & $\mathrm{kWh}$ \\
\hline Сезонски фактор перформансе ТП: & 3,3 & - \\
\hline Сезонски фактор перформансе система ТП: & 3,2 & - \\
\hline Потрошња електричне енергије ТП: & 4.749 & $\mathrm{kWh}$ \\
\hline Потрошња електричне енергије гријача: & 232 & $\mathrm{kWh}$ \\
\hline Потрошња ел. енергије пумпе топлотног извора: & 0 & $\mathrm{kWh}$ \\
\hline Губици резервоара (бојлера): & 376 & $\mathrm{kWh}$ \\
\hline Примарна уштеда енергије: & 11.435 & $\mathrm{kWh}$ \\
\hline Смањење СО 2 емисије: & 2.830 & $\mathrm{~kg}$ \\
\hline
\end{tabular}

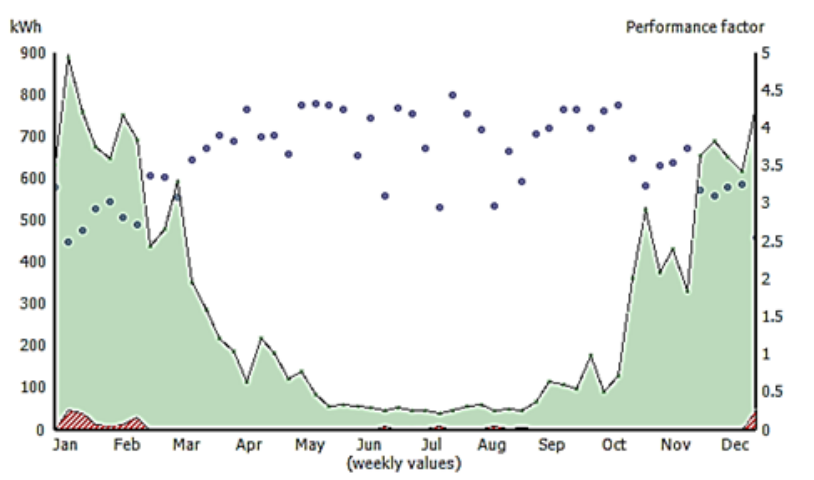

$\square$ Heat pump (15,518 kWh) Auxiliary heating $(232 \mathrm{kWh})$

Слика 8: Енергетски дијаграм и промјена $S P F$ фактора током године - ТП ваздух/вода за ниско ЕE објекат

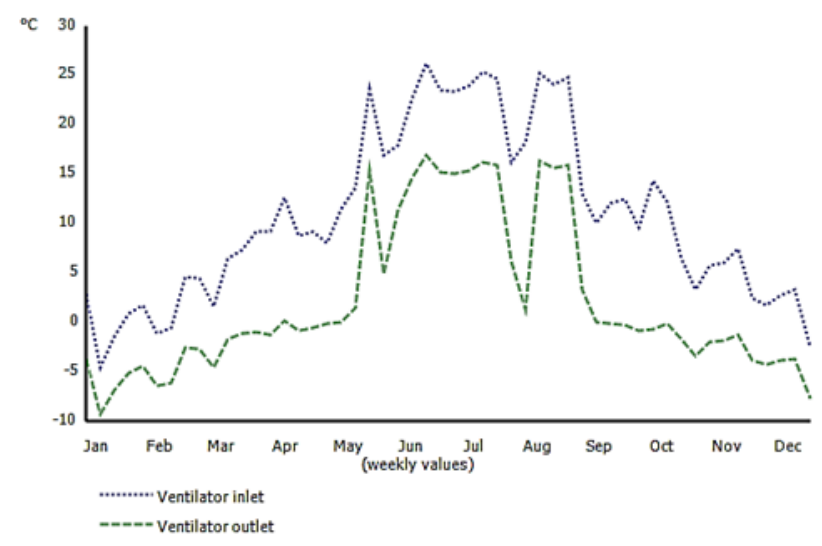

Слика 9: Температурски дијаграм - ТП ваздух/вода за ниско ЕЕ објекат

Овдје је разматран случај када је специфична потрошња топлоте по $\mathrm{m}^{2}$ тj. $90 \mathrm{~W} / \mathrm{m}^{2}$ самим тим већи су и захтјеви за топлотном енергијом (класа $\mathrm{K}_{3}$ разред $\mathrm{R}_{8}$ ). Због слабије термоизолације тј. већих топлотних губитака у околину потребна је топлотна пумпа веће снаге у односу на претходна два случаја да би се остварило пројектовано грејно оптерећење. Топлотна пумпа ваздух/вода је у бивалентној паралелној спрези са електричним гријачем од $2 \mathrm{~kW}$ који се активира када су пикови за топлотном енергијом велики. Енергија коју испоручи овакав систем у овом случају је за 87,72 \% већа од енергије коју испоручи систем у случају просјечно енергетски ефикасног објекта а 2,57 пута већа од енергије која је потребна за ниско енергетски ефикасан објекат. Ако би се користио систем са циркулацијом топле потрошне воде губици би се повећали за додатних $898 \mathrm{~kW}$ у односу на систем без циркулације. У поређењу са гасним котлом истих карактеристика цијена $\mathrm{kWh}$ топлотне енергије за 56,79 \% нижа од цијене гријања на гас.

\section{8. ЗАКЉУЧАК}

Топлотне пумпе представљају револуционарно решење на пољу технике гријања због тога што користе природне ресурсе (њихову топлотну енергију) да би задовољиле енергетске (топлотне) потребе крајњих корисника.

Из симулације види се да најмању цијену гријања по $\mathrm{kWh}$ има случај ниско енергетски ефикасног објекта у износу од 3,731 дин./kWh с тим да захтијева три пута већу специфичну потрошњу по $\mathrm{m}^{2}$ и мале инвестиције у термоизолацију објекта.

Најидеалнији случај јесте са високо енергетски ефикасним објектом специфичне потрошње од $30 \mathrm{~W} / \mathrm{m}^{2}$ али захтијева већа инвестициона улагања у термоизолацију са цијеном гријања од 6,782 дин./kWh. Просјечно енергетски објекат $\left(45 \mathrm{~W} / \mathrm{m}^{2}\right)$ је најбоље решење на енергетском и економском пољу са ценом гријања од 5,35 дин./kWh и највећим сезонским фактором перформансе од 3,9. Оно што је главни "камен спотицања" у коришћењу оваквих система јесте њихова цијена и заступљеност на тржишту.

\section{9. ЛИТЕРАТУРА}

[1] А. Ченејац, Р. Бјелаковић, А. Анђелковић, Неконвенционални системи грејања: теоријске основе, примена и примери прорачуна, Факултет техничких наука - Универзитет у Новом Саду, Нови Сад, 2017.

[2] Б. Јаћимовић, С. Генић, Топлотне операције и апарати, Машински факултет, Београд, 1992.

[3] GeoT*Sol софтвер за прорачун топлотних пумпи, www.valentin-software.com

\section{Кратка биографија:}

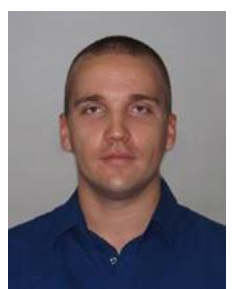

Драгиша Гутовић рођен је у Требињу 1993. године. Основну и средњу школу завршио у Гацку. Основне студије Машинства - Енергетика и процесна техника на ФТН завршио 2017. године. Мастер рад на истом факултету одбранио 2018. године. 